\title{
A place for 'Robin Hood' in the 21st Century: A measured call for Criminal Justice reform ${ }^{1}$
}

Without trying to sound too alarmist, it is reasonably safe to point out that globally the world is still reeling from the economic crash, or 'Black Friday' as it is also referred to as, that occurred in 2009. And while there have been other notable economic crashes in the past 100 years (e.g., the September 3, 1929, and October 19, 1989), the most recent financial crisis that started in 2007 is still evident in 2010 (e.g., the May 6, 2010 and the "Flash Crash"). The economic turmoil has had an impact on virtually all sectors of society. Countries such as Greece, Spain, Haiti, the United States, and most recently England and Ireland have all taken dramatic steps to try and curb the financial strain on their respective countries.

As sophisticated as economists have become with their scientific simulation models, there is no clear crystal ball predicting as to what the future holds. But what does appear to be a relatively 'safe' observation is the suggestion that 'time are a changing.' Therefore, in a prudent and arguably responsible manner, nations have begun to proverbially 'tighten their belts'. Among those areas where belt tightening has been evident includes the criminal justice systems of countries; because over the past 50 years most criminal justice systems have been "marked by ever-growing budgets, massive prison construction, the demonstrated failure of rehabilitation and deterrence theories, stubbornly high recidivism rates... including particularly frightening increased in juvenile crime" (Colson 2001, p. vii).

However, in order to make sound policy decisions, ideally, requires an informed evidence-based decision-making process. Yet, from whom or where such guidance and information should come from is not necessarily universally embraced. For, as is well known and documented among criminologists and academics who study the criminal justice system and their related issues, there have been, and continue to be, competing explanations and rationales for how best to respond to the call for greater accountability. The lack of uniformity as to which approach (i.e., solution) is 'best' is in-part reflected in the increasing complexity of the world we live in today as well as further compounded by what can generically be referred to as the "knowledge and information explosion". For example, several decades ago, Diebold (1969, p.7) observed that, "half of the scientific research conducted in the United States since the Republic was founded has been crowded into the last eight years, 90 per cent of all the scientists who have ever lived in the history of mankind are alive today." 2 The same, or similar, observation can be made about the body of knowledge, the expanse of criminological theories, and responses to crime have proliferated dramatically since criminal justice became a recognized social

1 The paper is based on a presentation at the "Criminal justice in Europe: Challenges, principles and perspectives" held in the City of Luxembourg, Oct. 22-24. I would like to acknowledge the support of Prof. Stefan Braum and my research assistant Crystal Hincks.

2 It is estimated that the rate of new information doubles every six months and that we learn as new today is obsolete in two years - remember the floppy drive or the Sony Walkman? 
science in the early $1920 \mathrm{~s}$ at University of California in Berkley under the leadership of August Vollmer (Wright and Fox 1978). Today, there are literally thousands of criminal justice programs to be found around the world. But, has this body of information and reservoir of knowledge resulted in a world that is safer with fewer crimes and criminals? Arguably not.

This article draws on the recent economic events to forward a (not so new but one whose time may finally be here) scenario that calls for reforms, or a 'paradigm shift', to criminal justice systems as we currently know them to be. It will be suggested that the time is right, if not overdue, to implement a more effective way to maintain social order than relying on the conventional practices of crime control that have dominated criminal justice systems globally. In this article, we will forward a concept that can be applied equally across all the major elements of the criminal justice system. However, before doing so, we will first turn our attention to what is meant by a criminal justice system as it is a concept that is also sometimes not well understood (see, generally, Boydell and Connidis 1982).

\section{The essence of the criminal justice system}

"More money is put into prisons than into schools. That, in itself, is the description of a nation bent on suicide" - Kozal, 1992.

It is a well documented fact that ever since humans have evolved from bands and tribal existence into the modern, largely, urbanized states of today, we have increasingly moved towards formalizing the norms and values of the day into codified laws (see, generally, Wright and Fox 1978). The establishment of laws can, from a social scientist's perspective, be divided into two main camps of thought. The consensus perspective argues that laws are a reflection of a common good. This perspective embraces a sort of utilitarian approach whereby it is believed that laws reflect the need for social order and are representative of widely held values and norms within a particular society. The model also asserts that justice is impartial in that it treats everyone equally before the law. In addition, law is seen as the most utilitarian way of resolving disputes. In accordance with the consensus model, the criminal justice system is seen to work in a cooperative manner so as to ensure a fair and just process in the administration of justice. Conversely, the conflict perspective embraces the position that laws are simply an expression of those who hold the power and use laws to control and maintain order over those less powerful in society. In addition, the conflict perspective tends to view the criminal justice system as an adversarial model in which the major elements of the criminal justice system do not work in a synchronistic manner. For example, while the police focus on detection and apprehension the courts focus on mitigating accountability by taking into account a multitude of factors ranging from such details as the number of priors, age of the offender, mental and emotional maturity of the offender, and relative gravity of the offence.

As with most pedagogical positions in the social sciences, there is no 'right' or 'wrong' answer, but the current position within the growing number of criminological and criminal justice camps is that given the heterogeneous composition of our populations (i.e., the diversity of race, culture and ethnicity), in today's world it is impossible, if not 
impractical, to have a legal system based on the consensus model alone (see Burtch 1992).

Furthermore, the current legal systems around the world are largely comprised of political laws or scientific laws. That is, they are made-up laws in that they are largely reactive to events of the time. Such law making is subject to disenfranchising some sectors of one society over another. For example, the new laws pertaining to terrorism, or the laws pertaining to gangs, or to the drug concerns, or to unwanted foreigners, among others, are not seen to be equally grievous by all.

The fact that our concept of maintaining social order and the 'social contract' are premised on artificial laws whose creative legislation are the livelihood of the, often, well trained and articulate minds of lawyers underscores two fundamental principles which appear to have been long since ignored or forgotten. It can arguably be said that in order to maintain a sense of social order, or social control, that humankind needs formalized laws so that societies can evolve and endure. Given both the complexity of human beings and the cultural and social diversity of most societies, those who subscribe to the need for social control over social order argue that if societies did not formalize their norms and values then people would not know how to respond to, or react towards, each other without creating conflict and societies would inevitably dissolve into chaos, or at the least social and/or political disarray. The question arises then what laws to apply and what is (as opposed to should be) the rationale behind them? Any response must bear in mind that legal systems are always in motion. That is, legal systems are dynamic and not static. However, virtually every religion, philosophical principle, and faith based group subscribe to two fundamental natural laws which, while dynamic, are static in their principles.

Drawing from the work of Maybury (1993), the two fundamental natural laws are:

1. Do all you say you are going to do; and

2. Do not encroach on other persons or their property.

In addition to these two common law principles and their simple seventeen words, the criminal justice system (CJS) can also be divided into the two key schools of criminological thought. The first school of thought to be articulated in the late $1700 \mathrm{~s}$, by the Italian philosopher and politician Cesare Beccaria (1738-1794), spawned what is more commonly referred to as the "classical school of thought". Becarria's ideas were largely expressed in his landmark treatise On crimes and punishment, which was published in 1764. There are four general and grand principles that epitomize the classical doctrine. They include: 1) the notion of equality for all under the law; 2) the principle of liberty, which asserts that only the law can decree punishment for a crime; 3) that law should be utilitarian and hence not be premised on retaliation and retribution; and 4) all punishment should be humane and there is no need for torture or cruel punishment.

Because the classical doctrine subscribes to the notion of free will, laws are seen to serve as a mechanism for deterring wrongful behavior as opposed to forcing compliance. Meanwhile, the other primary school of thought is the "School of positivist criminology" which was pioneered by another Italian criminologist, Cesare Lombroso (1835-1909). Again, in essence the positivist's principles are based on determinism and treatment. Human behavior is deemed to be deterministic, predictable, and subject to scientific understanding. As opposed to focusing on guilt or innocence, the positivist ideology embraces rehabilitation, reform, restorative justice, acknowledges mitigating circum- 
stances, and asserts that intervention should be individualized. Ironically, scholars such as Hackler (2007:65) argue that "neither of these schools serve us well in terms of reducing crime..." and that criminologists "should move on."

Most legal systems are premised on the 'classical' doctrine which allows minimal provision for any intervention before a crime is committed (Boydell and Connidis 1982). The legal system is also premised on the assertion that it is possible to control behavior and that control can be exacted through the creation of law. In fact, the criminal justice system is about what Jason Ditton (1979) refers to as "controlology" or as Nils Christie (1994) refers to it as 'crime control as industry'. Such a position does not readily allow for proactive measures such as restorative justice and crime prevention through social, cultural, or environmental manipulation - all of whose varying principles can found in different criminological theories.

As we've moved from customary type law to more statutory based law we've seen an ever increasing expansion of the social control network with questionable return on investment. And while it can be argued that man-made laws are created with the genuine objective of trying to ensure and maintain justice as they are often pragmatic and call for positive action (e.g., as home invasions become a growing concern in North America), new laws are created to specifically target the crime and the offender(s). Another such example occurred in the late $1980 \mathrm{~s}$, when Canadian law-makers revamped the classification of rape into three different levels of sexual assault in an attempt to better capture the diversity of the crime as well as to demonstrate the different levels of social consensus as to the relative depravity of the crime (see Burtch 1992). However, in the end, the three levels of sexual assault still speak to the second common law principle mentioned above: "do not encroach..." Another example of where man-made laws may further confabulate their underlying intention is that consensus could be compromised. For example, under common law, the punishment for murder was the taking of the offenders' life. However, in the ensuing generations there are fewer than 60 countries that still maintain capital punishment in law and practice ${ }^{3}$ (e.g., the United States, China, and most Muslim based countries still practice use the death penalty). In most corners of the world, the mitigating circumstances of the 'murder' are subject to a wide range of punishments. With the exception of such legal models as Scharia law, it is possible to ask for 'blood money' as opposed to another persons' life or liberty. Scharia law allows for absolute pardoning of a murderer. In fact, the law can be described as based on the foundation of compassion and mercy. Admittedly, these points can be debated, but the point is that laws such as the Scharia remain 'true' to their divine basis and have not been tinkered with as have virtually all Western legal systems (Halm 1999).

As I do not profess to have an expert command of the legal systems, I trust the point has been made that with the exception of a few legal systems, we have seen the erosion of common law principles at the expense of the proliferation of man-made laws and a legal system that has become increasingly dependent on 'evidence based' decision making which has moved from simple testimonies to a whole new consignment of 'businesses', such as expert witnesses, DNA evidence, a range of forensic type evidence, etc. that in addition to slowing down the process of the court have added to the cost of the system. Yet, in-spite of all the 'new age' evidence that can be brought to bear on a case,

3 Countries such as Iran and Saudi Arabia still execute persons under the age of 18. 
our efforts to maintain social order through social control has not produced the anticipated results. For example, the following statistics are drawn from the American based Innocence Project; founded in 1992 by Barry C. Scheck and Peter J. Neufeld at the Benjamin N. Cardozo School of Law at Yeshiva University to assist prisoners who could be proven innocent through DNA testing, found that between 1992 and 2001 the project was successful in having some 100 death sentences overturned based upon post-conviction evidence. According to their study of the first 70 cases reversed:

- Over 30 of them involved prosecutorial misconduct.

- Over 30 of them involved police misconduct which led to wrongful convictions.

- Approximately 15 of them involved false witness testimony.

- $34 \%$ of the police misconduct cases involved suppression of exculpatory evidence.

$11 \%$ involved evidence fabrication.

- $37 \%$ of the prosecutorial misconduct cases involved suppression of exculpatory evidence. $25 \%$ involved knowing use of false testimony. ${ }^{4}$

It is when we learn of such facts that we should be reflective of Blackstone's ancient reminder that 'it is better to let ten guilty men go free than to convict a single innocent person', a mantra which should serve as the highest operating principle of any justice system. However, in its current iteration, criminal justice systems do not have all the safeguards, let alone the capacity to ensure such lofty principles can be upheld.

Having provided a brief overview of the convoluted nature of most criminal justice systems, it is then perhaps fair to ask: are the changes warranted, and do they produce the intended result - control crime and reduce anti-social behavior?

\section{The price of crime/social control: Are the brakes gone?}

Regardless of the country, or region of the world, most nations subscribe to a conventional approach to maintaining law and order through the formalized structure of what we commonly refer to as the 'criminal justice system' (i.e., policing, courts, and corrections). ${ }^{5}$ Collectively this 'system' has been increasingly brought into question for its relative ineptness to perform its responsibilities in accordance with some key indicators. As its overarching purpose, the CJS is supposed to accomplish several key objectives. They include helping to maintain social order, deterring criminal offending, sanctioning wrong doing, and rehabilitating offenders. Until fairly recently, most societies have let the system grow with unbridgeable enthusiasm and with minimal accountability. For example, Canada is a country of around 35 million inhabitants with a criminal justice system budget in 2006 in excess of $\$ 13$ billion dollars with an estimated impact of $\$ 70$ billion when one takes into account efforts to combat and deal with crime and its victims (Speech for the Minister of Justice and Attorney General of Canada, Vic Toews, Q.C. 2006). This is in sharp contrast to the early $1980 \mathrm{~s}$ when the budget was only $\$ 7.7$ billion - accounting for $2.6 \%$ of total government spending (see Canadian Centre for Justice

4 As of Nov. 2010 the Innocence Project has successfully assisted over 260 inmates in getting exonerated for crimes they did not commit. See http://www.innocenceproject.org/

5 Reiss (1971), among others, argue that the public should be considered part of the criminal justice system because of the public's offence-reporting function. 
Statistics, 1991) or in 1994/95 when the budget climbed to $\$ 9.9$ billion (a per capita of \$340) (Cost of Criminal Justice: John Howard Society 1997).

A recent posting on the British website for the "Centre for Crime and Justice Studies" points out that between 2004 and 2010, prison and probation spending rose over 35 percent in real terms, spending for policing grew nearly 50 percent between 1999 and 2009, and spending has also risen anywhere between 17 and 31 percent for different sectors of the judicial system (Centre for Crime and Justice Studies 2010). Yet in late 2010, the British government announced a 25 percent cut to the Home Office budget (Spending review 2010: Policing and criminal justice cut $20 \%$, 2010). Similarly, in the United States, which has one of the highest incarceration rates in the world and whose criminal justice budget rivals the GDP of many Third world nations, states like Texas are looking to add to the financial burden. For example, in 2009 the prison system in Texas was offering $\$ 1,500$ recruiting bonus for those willing to move to understaffed prisons (Rankin 2009). Yet an increasing number of American States are turning to the Council of State Governments' Justice Center. This non-profit organization uses evidence-based data to help States reduce jail bills by identifying alternative support and treatment programs for inmates and parolees (Rankin, 2009). Yet as Pfaff (2009) recently pointed out, between 1928 and 1978 the American prison rate hardly budged. But, between 1978 and 2008 the incarceration rate jumped sevenfold to a rate over around 740 per 100,000 people.

Several years ago the Ministry of Justice in The Netherlands engaged in an interesting project in which they attempted to expand their understanding of their criminal justice infrastructure within an international (i.e., nine reference countries) context. Although admittedly descriptive in nature, a number of notable findings relative to the focus of this article emerged. For example, police dissatisfaction with law enforcement was higher in the European countries surveyed than in either Canada or the United States (e.g., Netherlands $31 \%$ vs. $12 \%$ of unsatisfied respondents in Canada). The report concluded that further to the relative inefficiency of any of the countries to deal with conventional crimes, they were all considered poorly positioned to 'control' such offences as financial and economic crimes, the illegal market related crimes, and white collar type offences (van Dijk and Waard 2000).

Finally, the picture is similarly bleak in Canada, where the overall crime cost to Canadians is around $\$ 70$ billion per year, of which only about 2 percent is directed to rehabilitation programs. While similar scenarios can be used to further demonstrate that the plight of the current CJS is not limited to any one country, it is also noted that the shortcomings of the conventional criminal justice model also applies on an international scale. For example, at a major conference in Washington, DC in 2010 the 'father' of international criminal law M. Cherif Bassiouni announced that some international criminal tribunals are a sham and that others are mired in bureaucratic failures (Bassiouni "Quite Doubtful"... 2010). Bassiouni went on to point out that in order to effectively fulfill its mandate the international criminal tribunals would require "an exorbitant economic and administration infrastructure."

If there is any truism to the previously mentioned facts, then our criminal justice system is in dire need of 'new' ideas and 'new' approaches. As C.R. Jeffery (1990: 464) poignantly argued criminology and criminal justice require "the courage and vision to look beyond past solutions that have failed" or have minimally not resulted in the in- 
tended return of investment. More recently, Waller (2008) has argued similarly in his book that is premised on the notion that more laws have not, and never will, result in more order. As reflected in this article, the CJS has not only created a false sense of security, but has largely failed in delivering on its mandate.

Aside from the financial strain to the system as it currently exists, we can also point to the relative inefficiency of the system. If one of the goals of the system is to mitigate crime, sanction offenders, as well as rehabilitate them, then what is the appropriate indicator of 'success'? Within the western world, the United States has the reputation of having one of the highest (if not the highest) incarceration rates in the world. In 2002, for example, the number of Americans incarcerated exceeded, for the first time in their history, over 2 million people (United States vs. The World 2005). Yet, their recidivism rates and crime rates have been among the highest as well. Arguably, this fact would suggest that law and order based on a model of punishment is not an overly effective strategy for crime control. Similarly, to consider front ending resources into more policing (i.e., equipment, technology, and hiring - usually the first contact point for those becoming involved in the CJS -) is also deemed inefficient. For example, in 2009, Canada allocated an additional \$161 million to hire 1,000 more police officers and Crown prosecutors to assist with the backlog of crime and criminal cases. However, considering that officially conventional crimes have been on the decline in recent years, the only reasonable rationale is that given the complexity of cases and their associated penalties, that the system sees a need to expand its infrastructure rather than figure out how to make the system more efficient (Tackling crime 2009). For example, a recent Canadian survey shows that defendants with driving infractions are willing to go to trial because the severity of the penalties is seen as an incentive to go to considerable lengths to avoid conviction. Not only does this add to the burden of the judicial system but it compels the system to manage cases which are not necessarily overly grievous to society (In Service 2010). Similarly in 2009, the European Confederation of Policing and the various State members noted that crime is increasing and, in-spite of the financial woes, according to their president, "slashing police budgets is a dangerous and short-lived measure". President Heinz Keifer argued that by one country cutting its budget it would have a negative effect on neighboring countries. Aside from a lack of clear evidence and poor logic, Keifer would appear to be relying on the 'fear factor' among the public to try support his position.

Even if it were possible to argue for more policing and find the monies to support such initiatives, there is the critical issues of 'value for money' to be considered. Several years ago, Aromaa et al. (2003) prepared a report for in which they provided data on police productivity in Europe and North American between 1995 and 1997. As shown in Figure 1, the results are considered less than impressive when one takes into account the training, education, and cost of hiring and maintaining a police force. 
Figure 1: Productivity of the Police: Suspects per 100 Police Officers

\begin{tabular}{|l|l|l|l|}
\hline Finland & 2692 & Isreal & 360 \\
\hline USA & 2260 & Macedonia, FYR & 353 \\
\hline Canada & 1043 & Slovenia & 332 \\
\hline Germany & 872 & Slovakia & 251 \\
\hline Netherlands & 845 & Italy & 249 \\
\hline Greece & 769 & Estonia & 225 \\
\hline Austria & 684 & Rep. of Moldova & 201 \\
\hline Norway & 684 & Croatia & 173 \\
\hline England \& Wales & 558 & Cyprus & 137 \\
\hline Portugal & 475 & Lithuania & 132 \\
\hline Hungary & 415 & Ukraine & 122 \\
\hline Poland & 404 & Spain & 102 \\
\hline Romania & 404 & Latvia & 100 \\
\hline France & 385 & Kazakhstan & 82 \\
\hline Sweden & 371 & Russia & 79 \\
\hline Ireland & 366 & Armenia & 53 \\
\hline
\end{tabular}

Source: Aromaa, K., Leppa, S., Nevala, S., and Ollus, N. (2003). Crime and criminal justice in Europe and North America 1995-1997: A report on the sixth United Nations survey on crime trends and criminal justice systems. European Institute for Crime Prevention and Control. Helsinki, Finland.

Figure 2 profiles four different countries and their policing systems. One of the notable observations is the fact that regardless of the ratio of police officers, or model of policing, or police budget, none of the countries can boast a very efficient or effective law enforcement entity. Ironically, how does a financially strapped country like Pakistan justify, let alone find the money, to increase police officers salaries by 30 percent in recognition of the dangers they face when dealing with the Taliban (Ali 2009). 
Figure 2: Profile of policing in four countries for 2006

\begin{tabular}{|l|l|l|l|l|} 
& CANADA & GERMANY & FINLAND & $\begin{array}{l}\text { UNITED } \\
\text { STATES }\end{array}$ \\
\hline POPULATION & $33,487,208$ & $82,110,097$ & $5,250,275$ & $307,212,123$ \\
\hline $\begin{array}{l}\text { \# OF POLICE } \\
\text { OFFICERS }\end{array}$ & 62,461 & 250,284 & 8,312 & 683,396 \\
\hline $\begin{array}{l}\text { RATIO OF PO- } \\
\text { LICE TO CITI- } \\
\text { ZENS }\end{array}$ & $1.914:$ & $3.035: 1,000$ & $1.579: 1,000$ & $2.236: 1,000$ \\
\hline $\begin{array}{l}\text { POLICING } \\
\text { BUDGET }\end{array}$ & $\begin{array}{l}\text { EUR } 7 \\
\text { billion }\end{array}$ & $\begin{array}{l}\text { EUR } 362 \\
\text { million }\end{array}$ & $\begin{array}{l}\text { EUR } 576.60 \text { milli- } \\
\text { on }\end{array}$ & $\begin{array}{l}\text { EUR } 70 \\
\text { billion }\end{array}$ \\
\hline $\begin{array}{l}\text { POLICE MO- } \\
\text { DEL }\end{array}$ & Community & Paramilitary & Community & Community \\
\hline $\begin{array}{l}\text { Crime Rate } \\
\text { Per 100,000 }\end{array}$ & $8,317.24$ & $7,628.46$ & $9,825.43$ & $3,764.78$ \\
\hline
\end{tabular}

Source: http://www.unodc.org/unodc/en/data-and-analysis/Tenth-CTS-full.html (accessed Nov. 01, 2010).

Yet the irony is that the public is generally quite supportive of its law enforcement (and criminal justice system as a whole) (see Waller 2008). However, according to the 2009 Global Corruption Barometer, policing and corrections do not perform well in terms of their level of corruptability. For example, Figure 3 shows that globally the police and the judiciary do not fair as well as educational services or even medical services. Regionally, according to Transparency International, in 2010, North America and Australia are the least corrupt while Western Europe ${ }^{6}$ performs a little less well, but is still better than Eastern Europe (Corruption perception index 2010 result, 2010). However, while perhaps revealing, it should also be noted that the index is not without its share of criticism (see Wilhelm 2002; Endre 2002; Galtung 2006).

6 Denmark was the lone Western European exception as it scored the highest as the least corrupt country globally. 
Figure 3: Percentage of people who reported paying brides (2006-2009), by service type

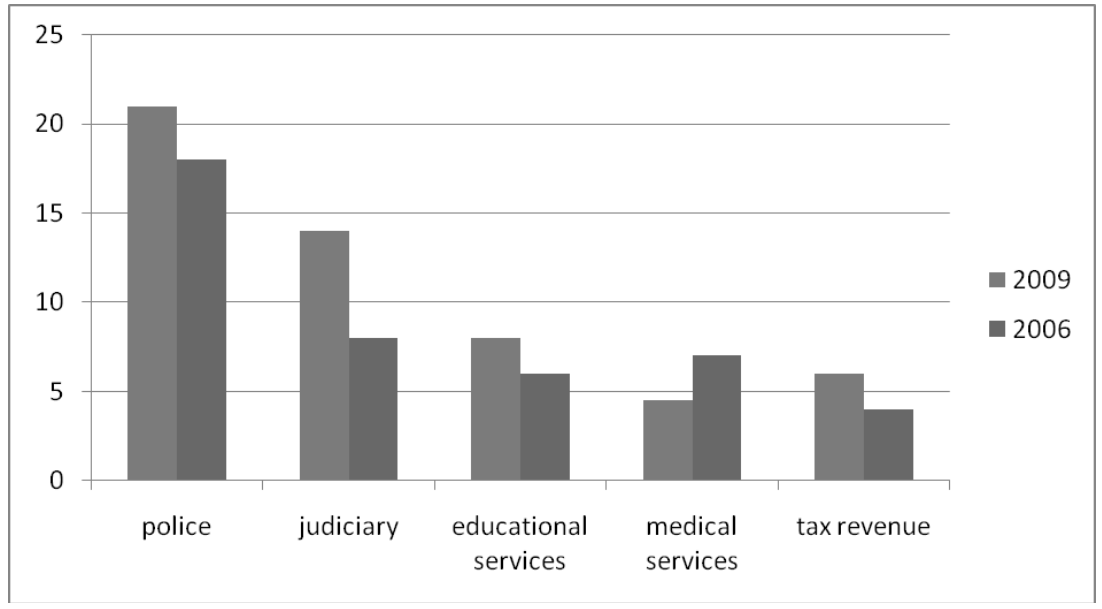

Finally, another aspect that can be pointed out to support the assertion that the criminal justice system needs to look beyond its basic 'law and order' or 'tough on crime' mantra is the erosion of community spirit and support in fighting crime (see Engaging communities in fighting crime 2008). Yet, as Irwin Waller (2008) from the University of Ottawa (Canada) recently pointed out that as much as we might want to believe that the average citizen embraces 'law and order' that in fact, according an American Gallop Poll that Americans were actually more supportive of investing in education and jobs. Between 1990 and 2003 the support rating rose from 57 percent to 69 percent. Conversely, support for more police and prisons dropped from 36 percent support to 29 percent support in 2003.

In spite of the apparent pessimism there is sufficient evidence that the brakes have not completely given out. It is possible to stop the run away criminal justice budget and obsession with crime control. There have been a number of road bumps that show that it is possible to not only slow the conventional process down but to perhaps divert the direction in how we think and respond to crime.

\section{If it doesn't work why not fix it!}

As with any organization or entity that is steeped in history, tradition, and/or political ideologies, they are often resistant to change, let alone receptive to evolving. Admittedly, most such entities will adapt and morph somewhat to try and reflect the social, economic, and cultural climate, but once entrenched we seldom ask the 'hard' questions: "do they work and do they offer the best return for our investment?" This article is premised on 
the fundamental assertion that criminology and criminal justice must develop and embrace a 'new' approach that emphasizes social order over social control.

As stated at the outset of this article, crime prevention is neither a new nor novel concept to the CJS. Crime prevention can express itself in a number of different ways. Briefly, there are three main type of crime prevention: primary, secondary and tertiary prevention. Primary prevention focuses on individual or family level factors such as targeting risk factors as school, family, and other pro-social or protective factors. By focusing on individual or community factors, primary prevention attempts to introduce initiatives that prevent the crime before it occurs. One of the more infamous examples occurred in the $1980 \mathrm{~s}$ with the "broken window" initiative that involved going into problem areas and improving their physical conditions to reduce their receptivity to criminal activity (see Wlison and Kelling 1982). Secondary prevention involves targeting high-risk social settings that are known to contribute to criminal activity. Secondary prevention strategies can include school programs to educate young persons' as to the risk of getting involved in gangs or introducing education programs in source countries of human trafficking to reduce the risk of potential victims from being fraudulently recruited (Perrin 2010). Finally, tertiary prevention involves initiatives that are introduced after a problem has already presented itself. For example, in the aftermath of 9/11 most countries altered their border security and immigration practices to risk the risk of future terrorist attacks (see Winterdyk and Sundberg 2010). Historically, we have seen all three types of crime prevention have been used with varying degrees of success (see Farrington and Welsh 2002). However, what is to be noted is that when implemented properly, crime prevention initiatives tend to be significantly more effective as keeping potential offenders out of the CJS and consequently reduce the financial burden to the CJS.

While it is beyond the scope of this article to attempt to provide compelling evidence that supports one crime prevention approach over another, it is argued that any crime prevention initiative should focus on factors that are observable, measureable, and which can be implemented in a cost efficient manner-commonly referred to in the literature today as 'social return on investment'. The factors themselves can be divided into crime 'risk' and 'protective' factors. Risk factors are those variables or indicators that increase the likelihood of someone becoming involved in ant-social or criminal activity. Some of the more readily recognized indicators include: poverty, low literacy rates, poor housing/living conditions, limited access to health and mental health care, and early contact with social service and/or the criminal justice system.

Meanwhile, protective factors as the term implies are those factors that can help shield individuals or communities from getting involved in crime. Some of the protective factors targeted to date include: focusing on enforcing positive attitudes, values or beliefs; teaching conflict resolution skills; supporting student success at school; creating employment, recreation, or other enriching opportunities; and promoting quality health and residential services and facilities.

Based on what has been presented, it appears factually evident that contrary to media and/or political rhetoric that the public may well be receptive to not only entertaining alternatives but actually embracing them. However, as with any social change, it is probably best to start out with measured control and accumulate the necessary evidence and allow for any adjustments to the 'new program(s)' without compromising their 
potential. Therefore, what is recommended is that governments at the local, regional, national, and international level begin to make firm commitments to earmarking a 'small' but fixed percentage of their criminal justice budgets to identify crime prevention initiatives that are based on observable and measurable crime risk and which can be addressed through initiatives that focus on protective factors and/or the building and sustaining of protective and resiliency factors.

Drawing on the old adage that 'our youth are our future' a disproportionate amount of the allocated funds should be directed to addressing youth-at-risk and their protective factors. In addition, resources should be allocated to helping to build resiliency among the at risk populations (e.g., children, women, the elderly, new immigrants, the experiencing economic hardship, etc.) across the social, psychological, cultural, and physical aspects of their lives so that they can navigate and negotiate their way through life (see, for example, Resilience Resource Centre 2010). In addition to focusing on crime prevention and resiliency protocols, attention should also be directed to further supporting and expanding the use of restorative justice (RJ). Even though RJ is not a type of crime prevention, it is an approach with a rich history (Gavrielides 2007) that focuses on building community capacity through offender-victim reconciliation as well as on establishing social order without reliance on all the pejorative entrapments of the conventional criminal justice system. As Sherman and Strang (2007) suggested in their extensive review of restorative justice initiatives, it "is ready to be put to far broader use."

In the end, I (and others who have also championed a paradigm shift to how we view the administration of criminal justice) am not calling for an 'all or nothing' approach. Human behavior remains to complex and social scientists do not yet understand human behavior well enough to risk surrendering that social control mechanism that has allowed societies to maintain social order - but usually at a price. To embrace an approach similar to what has been advocated in this article is a call for a return to social order over social control. It is a call for not only fiscal responsibility but also a call for honoring fundamental human rights principles and being honest about "what works".

\section{Summary - "Doing more with less"}

This article began by pointing out the current financial difficulties that many nations are currently facing. The factual reality of this situation was used to justify a strong call for action to what has to date in most countries only been given superficial attention. The first part of the article focused on illustrating the fact that criminal justice systems, as we generally know them to be today, represent a massive enterprise that does not operate in an efficient or effective manner. In fact, it has in many cases eroded public support and public respect. Yet, the fact remains that governments continue to fuel the conventional approach to crime control at social, economic and political cost that offers a bleak future for social order in the world. For example, our over-reliance on punishment and imprisonment only serves to further destabilize communities and the more destabilized they become the inevitable result is more crime (see Colson 2001). The dramatic rise in transnational crimes such as smuggling and human trafficking, incidents of genocide 
and corporate crimes are reflective of a global community that has lost (or at least losing) control in its fight against crime and is expressive of a break-down in our social order.

Rather than continue down the reactive and punitive path and one that has yet to demonstrate a good return on investment, it is posited that we need to shift from a reactive oriented system to one that is much more proactive as well as one that is oriented to promoting social order, building community capacity, and demonstrating a positive measureable return on investment. However, recognizing the complexity of human behavior and the diverse reasons as to why people commit crimes, this article is not calling for an all or nothing approach but one that attempts to strike a balance between the conventional model and one that provides and supports proactive, evidence-based research to better guide policy. The proactive strategies need to place a greater emphasis on crime prevention, resiliency building, and the use of restorative justice.

It is recommended that in order to enliven the paradigm shift, governments need to make a commitment to permanently reallocating an increasing amount of their existing $\mathrm{CJ}$ budget to the proactive programs and initiatives that target crime risk and protective factors and that demonstrate a clear return on investment. As such initiatives and programs expand there will be a drop in crime which can then be accompanied by a decline in the CJ budget with the reallocation of the 'extra' money into supporting and sustaining the protective and resiliency programs for generations to come.

As stated at the outset, we have perhaps never been better positioned because of the global financial crisis to embrace (radical) alternative paradigms that a growing body of scientifically grounded evidence has shown can, and does actually work. But the challenge still remains as to whether we are willing to embrace the opportunity for change and to divert monies from our current criminal justice budget and direct it to more cost-efficient and cost-effective initiatives. The alternative is we continue to erode the social fabric (i.e., we'll end up with more victims) of society and to paraphrase the esteemed psychiatrist Karl Mennigner (1968), societies end up with the crime they deserve.

\section{References}

Ali, F. (2009). Pakistan boosts salary as violence grows. http://in.reuters.com/article/idINIndia-39159920090421 (accessed Nov. 09, 2010).

Aromaa, K., Leppa, S., Nevala, S., Ollus, N. (2003). Crime and criminal justice in Europe and North America 1995-1997: A report on the sixth United Nations survey on crime trends and criminal justice systems. European Institute for Crime Prevention and Control. Helsinki, Finland.

Bassiouni "Quite Doubtful" International Criminal Court Will Succeed -- The Failures, Challenges, and Future of International Criminal Law. (March 31, 2010). http://www.insidejustice.com/law/index.php/ intl/2010/03/31/p256 (accessed Nov. 09, 2010).

Burtch, B. (1992). The sociology of law: Critical approaches to social control. Toronto: Harcourt Brace Jovanovich CDN.

Christie, N. (1994). Crime control as industry. NY: Routledge.

Cost of Criminal Justice: John Howard Society. (1997). http://www.johnhoward.ab.ca/pub/C48.htm (accessed Nov. 08, 2010).

Centre for Crime and Justice Studies. (2010). http://www.crimeandjustice.org.uk/ (accessed Nov. 10, 2010).

Corruption perception index 2010 result (2010). http://www.transparency.org/policy_research/surveys_indices/cpi/2010/results (accessed Nov. 10, 2010). 
Diebold, J. (1969). Man and the computer: Technology as an agent of social change. New York: Frederick A. Praeger.

Dijk, F. van, \& de Waard, J. (June 2000). Legal infrastructure of the Netherlands in international perspective. Den Haag, NL: Ministry of Justice The Netherlands.

Ditton, J. (1979). Contrology: Beyond the New Criminology. London: MacMillan.

Engaging communities in fighting crime. (2008). http://www.direct.gov.uk/en/N11/Newsroom/ DG_078805 (accessed Nov. 15, 2010).

Farrington, D.P. \& Welsh, B.C. (Eds.). (2002). Evidence-based crime prevention. NY: Routledge.

Galtung, F. (2006). "Measuring the Immeasurable: Boundaries and Functions of (Macro) Corruption Indices," in Measuring Corruption, Charles Sampford, Arthur Shacklock, Carmel Connors, and Fredrik Galtung (Eds.). London: Ashgate. Pp: 101-130.

Gavrielides, T. (2007). Restorative justice theory and practice: Addressing the discrepancy. Helsinki, Finland: HEUNI.

Hackler, J.C. (2007). Canadian criminology: Strategies and perspectives. (4th ed). Toronto: Pearson/ Prentice Hall.

Halm, H. (1999). Shi'a Islam: From religion to revolution. Princeton, NJ: Markus Wiener Pub.

Maybury, R. J. (1993).Whatever happened to justice? Placerville, CA: Bluestocking Press.

Menninger, K. (1968). Crime and punishment. NY: Viking Press.

Perrin, B. (2010). Invisible chains. Toronto: Viking Press.

Pfaff, J. (Feb. 19 2009). Reform school: Five myths about prison growth dispelled. http://www.slate.com/ id/2211585/ (accessed Nov. 08, 2010).

Rankin, J. (2009, July 18). A real-estate guide to incarceration. www.thestar.com/printartcile/66804 (accessed Nov. 10, 2010).

Resilience Resource Centre. (2010). www.resilienceproject.org/ (accessed Nov. 21, 2010).

Sherman, L. \& Strang, H. (2007). Restorative justice: the evidence. London: The Smith Institute.

Sik, E. (2002). "The Bad, the Worse and the Worst: Guesstimating the Level of Corruption," in Political Corruption in Transition: A Skeptic's Handbook, Stephen Kotkin and Andras Sajo, (Eds.). Budapest: Central European University Press. Pp: 91-113.

Speech for the Minister of Justice and Attorney General of Canada, Vic Toews, Q.C. (2006). http:// www.justice.gc.ca/eng/news-nouv/spe-disc/2006/doc_31786.html (accessed Nov. 10, 2010).

Spending review 2010: Policing and criminal justice cut $20 \%$. (2010). http://www.u.tv/News/Spendingreview-2010-Policing-and-criminal-justice-cut-by-20/736afa78-ae5c-4737-a111-a0b75518a551 (accessed Nov. 10, 2010).

Tackling crime. (2009). Government of Canada. http://www.tacklingcrime.gc.ca/ocom/hig/index-eng.aspx (accessed Nov. 12, 2010).

United States vs. The World. (2005). http://www.defendingjustice.org/pdfs/factsheets/9-Fact\%20Sheet $\% 20-\% 20 U S \% 20 v s \% 20$ World.pdf (accessed Nov. 08, 2010).

Waller, I. (2008). Less law more order: The truth about reducing crime. Ancaster, ON.: Manor House Pub.Maybury, R. J. (1993). Whatever happened to justice? Placerville, CA: Bluestocking Press.

Wilhelm, P.G. (2002). "International Validation of the Corruption Perceptions Index: Implications for Business Ethics and Entrepreneurship Education". Journal of Business Ethics (Springer Netherlands) 35 (3): 177-189.

Wilson, J. Q., \& G. Kelling. (1982). The police and neighborhood safety: Broken windows. The Atlantic Monthly (March): 29-38.

Winterdyk, J. \& Sundberg, K. (2010). Border security in the A-Qaeda era. Boca Rattan, Fl.: Taylor and Francis.

Wright, B. \& Fox, V. (1978). Criminal justice and the social sciences. Philadelphia, PA: W.B. Saunders Co. 